Article

\title{
Inhibition of Virulence Gene Expression in Staphylococcus aureus by Novel Depsipeptides from a Marine Photobacterium
}

\author{
Maria Mansson ${ }^{1}{ }^{1}$, Anita Nielsen ${ }^{2}$, Louise Kjærulff ${ }^{3}$, Charlotte H. Gotfredsen ${ }^{3}$, \\ Matthias Wietz ${ }^{4}$, Hanne Ingmer ${ }^{2}$, Lone Gram ${ }^{4}$ and Thomas O. Larsen ${ }^{1}$ \\ 1 Center for Microbial Biotechnology, Department of Systems Biology, Technical University of \\ Denmark, DK-2800 Kgs. Lyngby, Denmark; E-Mail: tol@bio.dtu.dk \\ 2 Department of Veterinary Disease Biology, Faculty of Life Sciences, University of Copenhagen, \\ DK-1870 Frederiksberg C, Denmark; E-Mails: anini@life.ku.dk (A.N.); hi@life.ku.dk (H.I.) \\ 3 Department of Chemistry, Technical University of Denmark, DK-2800 Kgs. Lyngby, Denmark; \\ E-Mails: lokja@kemi.dtu.dk (L.K.); chg@kemi.dtu.dk (C.H.G.) \\ 4 National Food Institute, Technical University of Denmark, DK-2800 Kgs. Lyngby, Denmark; \\ E-Mails: mwie@food.dtu.dk (M.W.); gram@food.dtu.dk (L.G.) \\ * Author to whom correspondence should be addressed; E-Mail: maj@bio.dtu.dk; \\ Tel.: +45-4525-2724; Fax: +45-4588-4148.
}

Received: 22 September 2011; in revised form: 22 November 2011 / Accepted: 30 November 2011 / Published: 7 December 2011

\begin{abstract}
During a global research expedition, more than five hundred marine bacterial strains capable of inhibiting the growth of pathogenic bacteria were collected. The purpose of the present study was to determine if these marine bacteria are also a source of compounds that interfere with the agr quorum sensing system that controls virulence gene expression in Staphylococcus aureus. Using a gene reporter fusion bioassay, we recorded agr interference as enhanced expression of spa, encoding Protein A, concomitantly with reduced expression of hla, encoding $\alpha$-hemolysin, and rnaIII encoding RNAIII, the effector molecule of agr. A marine Photobacterium produced compounds interfering with agr in S. aureus strain 8325-4, and bioassay-guided fractionation of crude extracts led to the isolation of two novel cyclodepsipeptides, designated solonamide A and B. Northern blot analysis confirmed the agr interfering activity of pure solonamides in both $S$. aureus strain 8325-4 and the highly virulent, community-acquired strain USA300 (CA-MRSA). To our knowledge, this is the first report of inhibitors of the agr system by a marine bacterium.
\end{abstract}


Keywords: Photobacterium; Vibrionaceae; antivirulence; quorum sensing inhibition; agr

\section{Introduction}

Microorganisms are an attractive source of new natural products with antimicrobial properties [1,2], and the marine environment constitutes a prolific resource of bioactive microorganisms [3-5]. Many marine microenvironments stimulate the production of specific metabolites as a response to environmental factors [6]. It is likely that some of these metabolites mediate both intra- and interspecies microbial interactions, and can be seen as potential new scaffolds for development of drug lead candidates [6,7]. The increasing problem of antibiotic resistance among human pathogens highlights the need for novel therapeutic strategies [8]. The search for new avenues in microbial control has therefore been extended from traditional bacteriostatic or bacteriolytic compounds to compounds that target, for example, quorum sensing (QS) pathways [9-11]. Quorum sensing inhibitors (QSI) do not necessarily kill or inhibit the growth of a pathogen but rather modulate microbial phenotypes, for example by attenuating virulence [12,13]. In vivo studies with QS inhibitory compounds demonstrated how these can be used to slow the spread of infection [14] or enhance the clearance of pathogens from infected tissue [10].

Staphylococcus aureus is one of the main causes of nosocomial infections, and methicillin-resistant $S$. aureus (MRSA) are emerging at an alarming rate $[15,16]$. The virulence of $S$. aureus is ascribed to a number of virulence factors, including extracellular toxins such as $\alpha$-hemolysin encoded by hla, and cell surface adhesion factors such as Protein A encoded by spa [17]. Their expression is coordinated through several key regulators, of which the $a g r$ (accessory gene regulator) QS system is central [18]. This system is a classical two-component system with a sensor histidine kinase, AgrC, and a response regulator, AgrA, in addition to AgrB and AgrD which are responsible for the production of the quorum sensing signal $[19,20]$. agr-dependent QS is mediated via autoinducing peptides (AIP), 16-membered thiolactone macrocycles carrying a peptide tail that control virulence gene expression through the effector molecule RNAIII [21,22]. Structure-activity relationship studies (SAR) demonstrated that while the tail of the AIP is essential for $a g r$ activation [19,23], the macrocyclic ring is responsible for antagonistic activity [23]. This has led to the synthesis of global inhibitors based on truncated AIPs [23,24]; however, there are only few reports of natural antagonists of this system [24-27]. Nielsen et al. [28] recently developed a screening assay based on $S$. aureus lacZ reporter fusion strains, where the effect of compounds or extracts on expression of three key virulence genes (spa, hla, and rnaIII) and hence potential interference with the agr locus can be assessed. Subsequently, the assay was used to identify two xanthones as novel quorum sensing interfering compounds in S. aureus [28].

We recently established a global collection of marine bacteria with antibacterial activity [29]. The purpose of the present study was to determine if this strain collection also harbored organisms that produced other types of bioactive compounds and we screened pure cultures, crude extracts, and purified secondary metabolites from the collection for potential inhibitors of the agr system. One of the bacterial families we investigated was the Vibrionaceae. These bacteria are ubiquitous in marine and brackish environments and often associated with marine organisms [30]. The Vibrionaceae consist of seven genera, with the majority of species belonging to the Vibrio and Photobacterium genera. Vibrio spp. can 
be pathogenic to humans [31-33] or marine animals [30], but also occur in the commensal microflora of zooplankton [30] or live as bioluminescent symbionts with squid or fish [34-36]. The Photobacterium genus similarly comprises symbiotic [37,38] and pathogenic species [39-41]. Members of the Vibrionaceae produce broad-range inhibitory compounds [7,29]; however, only few of the antibacterial compounds have been isolated to date [42]. Antimicrobial compounds from Vibrio species include the pyrrolidinediones andrimid [43-45] and moiramide B [46] that inhibit fatty acid synthesis [47]. In addition, we recently reported the production of the potent pyrrothine antibiotic holomycin by a marine Photobacterium [45].

Herein, we report the isolation and chemical investigation of two novel depsipeptides produced by that same Photobacterium strain. The compounds, designated solonamides A and B, inhibit the agr QS system of $S$. aureus and therefore interfere with its virulence gene expression. This indicates that marine bacteria are a source of novel chemistry with potential use in antibacterial therapy.

\section{Results and Discussion}

\subsection{Identification of QS Inhibitors from Photobacterium sp.}

In an initial search for antimicrobial compounds we isolated strain S2753 related to Photobacterium halotolerans [29]. Subsequently, the known antibiotic, holomycin, was identified as responsible for its growth inhibitory activity [45]. When investigating ethyl acetate extracts of S2753 in an agar diffusion assay monitoring expression of the $S$. aureus virulence genes hla, rnaIII, and spa [28], we observed an increased expression of spa and decreased expression of hla and rnaIII. The inverse effect of the extracts on spa and hla/rnaIII expression, respectively, indicates the presence of at least one compound that interferes with the $S$. aureus agr QS system [28]. Secondary screening of the extract by explorative solid-phase extraction (E-SPE) [48] detected the potential QSI activity in a fraction that did not inhibit growth of $S$. aureus or $V$. anguillarum (data not shown). Bioassay-guided fractionation by diol and C-18 columns resulted in the isolation of two compounds active in the $S$. aureus agar diffusion assay (Figure 1). The activity of the pure compounds matched the initial activity of the extract, confirming that these compounds are responsible for the observed changes in gene expression.

Figure 1. Effect of solonamides (A and B) on hla, rnalII and spa expression. Solonamides ( $5 \mathrm{mg} \mathrm{mL}^{-1}$ ) were added to wells in TSA plates containing the 8325-4 derived lac $Z$ reporter strains PC322 (hla::lacZ), SH101F7 (rnaIII::lacZ), or PC203 (spa::lacZ). Incubation time was $15 \mathrm{~h}$ for plate I and II, and $35 \mathrm{~h}$ for plate III (plate numbering indicated with white letters). Solonamide B tested in two wells.

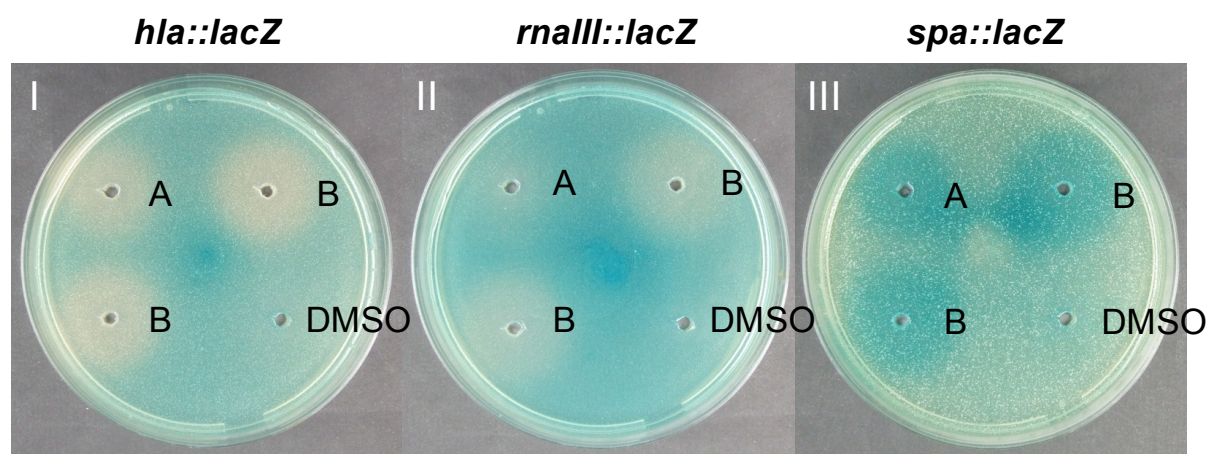




\subsection{Structural Elucidation of the Solonamides}

The solonamides were isolated as white powder with respective molecular formulas $\mathrm{C}_{30} \mathrm{H}_{46} \mathrm{~N}_{4} \mathrm{O}_{6}(\mathrm{~A})$ and $\mathrm{C}_{32} \mathrm{H}_{50} \mathrm{~N}_{4} \mathrm{O}_{6}$ (B) as determined by HRMS (1 ppm mass accuracy). Analysis of NMR data characterized the structures of the solonamides as cyclodepsipeptides consisting of four amino acids and a 3-hydroxy fatty acid (Figure 2). The amino acid composition was elucidated as alanine, phenylalanine, and two leucines for both peptides based on DQF-COSY and HSQC NMR data.

Figure 2. Structures of solonamides A and B produced by Photobacterium sp. strain S2753 and structure of natural group I AIP [21].

D-Ala<smiles>CCCC(CC(=O)N[C@@H](Cc1ccccc1)C(=O)N[C@@H](CC(C)C)C(=O)N[C@@H](C)C(=O)N[C@@H](CC(C)C)C(=O)O)OC(=O)C(C)C</smiles>

(R)-Hha
L-Phe

A

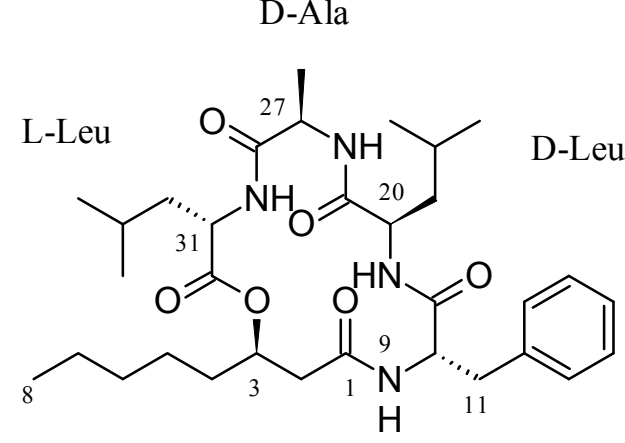

(R)-Hoa

L-Phe

B

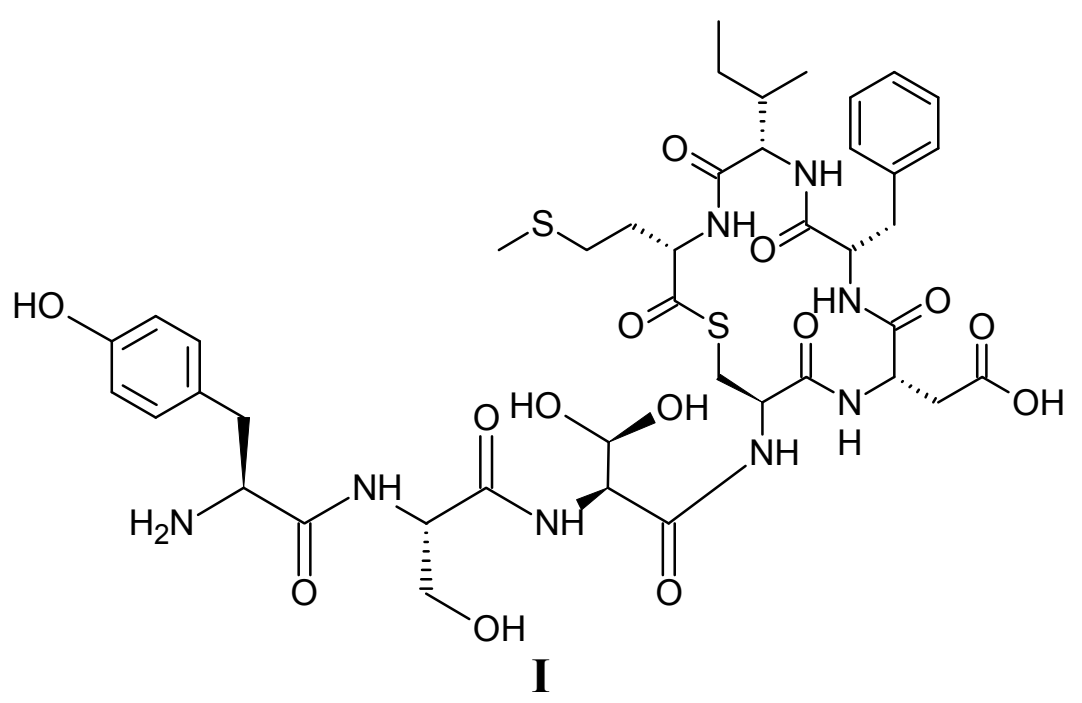

The spin systems of the amino acids were confirmed through strong and unambiguous H2BC correlations [49] and the carbonyl signals assigned by HMBC correlations. Through careful inspection of the DQF-COSY and H2BC NMR data, solonamide A was found to contain a 3-hydroxyhexanoic acid (Hha), while solonamide B contained a 3-hydroxyoctanoic acid (Hoa). Long-range HMBC and NOESY correlation data allowed the sequence of amino acids to be established as fatty acid-Phe-Leu-Ala-Leu (Figure in Supplementary Information). This was corroborated by MS-MS experiments giving the exact molecular formula of the fragments ( 2 ppm mass accuracy, see Supplementary Information). The signal from one oxygen-bearing carbon with a high carbon shift indicated an ester linkage. The ring closure linkage was secured by HMBC correlations from H-3 in the fatty acid moiety to the carbonyl 
in Leu and a weak NOESY correlation from H-3 to the Leu amide and H $\alpha$ protons. In total, this accounted for the ten degrees of unsaturation resulting from the macrocyclic ring, five carbonyls, and the phenyl group.

The absolute configurations of the individual amino acids were established by acid hydrolysis and Marfey's method with UHPLC analysis. Both peptides were found to contain L-Phe, D-Ala, and an enantiomeric pair of L-Leu and D-Leu. Acid hydrolysis of the reduced linear peptides and subsequent Marfey's derivatization specified the stereochemistry of the two Leu, exchanging the L-Leu peak (RT $3.77 \mathrm{~min}$ ) with a new peak (RT $3.73 \mathrm{~min}$ ), attributable to the corresponding alcohol. Thus, L- and D-stereochemistry was assigned as fatty acid-L-Phe-D-Leu-D-Ala-L-Leu in both solonamide A and B.

The absolute configuration of the fatty acid was established by NMR spectroscopic analysis of the ${ }^{1} \mathrm{H}$ and ${ }^{19} \mathrm{~F}$ chemical shift differences $\left(\Delta \delta^{S R}\right)$ in the $(R)$ - and $(S)$-Mosher's esters analysis of solonamide $\mathrm{A}$ and B. The absolute stereochemistry of C-3 in the 3-hydroxy fatty acid was established as $(R)$ in both depsipeptides (Figure 3).

Figure 3. Distribution of the $\Delta \delta$ values (ppm) calculated for the (a) 3-hydroxyhexanoic acid (Hha) and (b) 3-hydroxyoctanoic acid (Hoa) in the $(R)$ - and $(S)$-Mosher's esters.

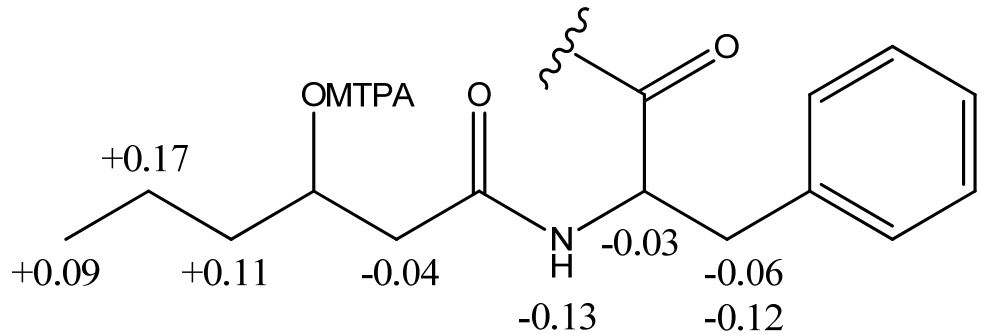

(a)

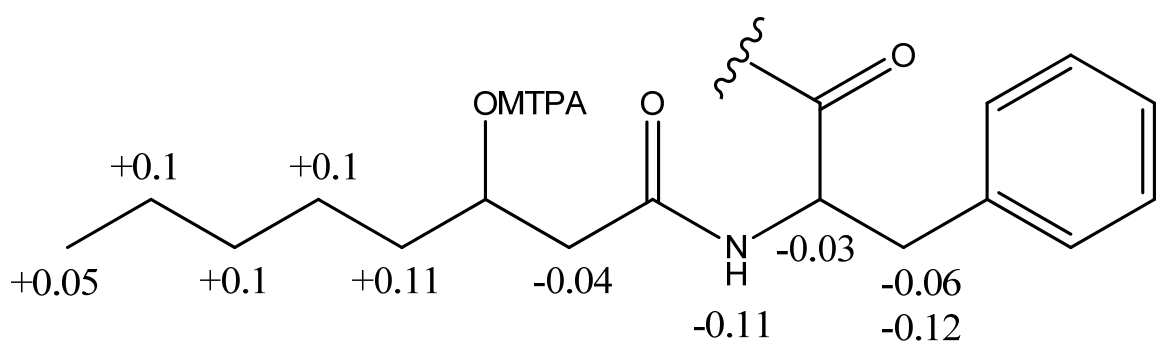

(b)

The yield of solonamides was up to $10 \mathrm{mg} \mathrm{L}^{-1}$, which is a high organic yield compared to that of other $\gamma$-proteobacteria [50,51]. This suggests that they could be storage compounds accumulated during growth. However, the solonamides were also produced on a chitin based minimal medium (Supplementary Information) which indicated that these compounds may be produced in the natural habitat of vibrios, such as chitinous zooplankton. In addition, D-alanine and L-leucine are incorporated in the structure; amino acids that are not present in the laboratory medium. Thus, the Photobacterium seems to produce these specific stereoforms rather than incorporating the available amino acids.

\subsection{Production of Solonamides by Related Photobacterium Strains}

To test whether the solonamides are also produced by strains related to our Photobacterium isolate, we compared strain S2753 with $P$. halotolerans $\mathrm{LMG} 22194^{\mathrm{T}}, P$. rosenbergii $\mathrm{LMG} 22223^{\mathrm{T}}$, and 
P. angustum S14 [52]. None of these strains produced solonamides (as confirmed by LC-UV/MS), and none affected virulence gene expression in the gene-reporter agar diffusion assay. None of the three strains inhibited growth of $V$. anguillarum, and holomycin, the antibiotic of S2753 [45], was not detected.

To the best of our knowledge, only two species of Photobacterium have been investigated for their secondary metabolites so far [51,53,54]. Oku et al. [51] isolated unnarmicin A and C from a marine Photobacterium strain MBIC06485 related to P. leiognathi. Like the solonamides, unnarmicin $\mathrm{A}$ and $\mathrm{C}$ consist of four amino acids (L-Phe, L-Leu, D-Phe, L-Leu) and a 3-hydroxyoctanoic and 3-hydroxyhexanoic fatty acid, respectively. The finding of the unnarmicins in another marine Photobacterium sp. indicates that production of such peptides could be a common feature in this group of bacteria, despite the absence of solonamides in any related strains that we investigated.

\subsection{Solonamides Interfere with agr}

To verify that the purified solonamides do in fact cause transcriptional changes in virulence gene expression and to assess if the effect is strain specific, we isolated mRNA from S. aureus 8325-4 and the community-acquired strain, USA300 at different stages of growth following solonamide exposure and monitored gene expression by Northern blot analysis. Solonamide B dramatically reduced the expression of both hla and rnaIII while increasing expression of spa, strongly indicating that the compound interferes with agr regulation (Figure 4). The decreased expression of rnaIII was even more pronounced in the highly virulent USA300 strain where high agr activity is suspected to be a main contributor to the virulence of the strain $[55,56]$. The solonamides did not affect the growth rate of the liquid $S$. aureus cultures. Solonamide A was able to increase spa expression, but caused only a marginal reduction of hla and rnaIII expression in both 8325-4 and USA300. The discrepancy between the Northern blot analysis and the agar diffusion assay (mainly with regard to hla) may be rooted in the much higher concentrations of solonamides that are used in the agar diffusion assay as compared to the Northern blot analysis. Also, the Northern blot analysis directly monitors the amount of mRNA shortly after solonamide addition, whereas the agar diffusion assay relies on the accumulation of $\beta$-galactosidase enzyme over a period of 15 or $35 \mathrm{~h}$.

The structural similarity of the solonamides and the AIPs (Figure 2) suggest that they may be competitive inhibitors of the $a g r$ system. Unlike the AIPs, the solonamides are cyclized through a 3-hydroxy fatty acid forming a lactone rather than a thiolactone. However, synthetic lactone and lactam variations of natural AIPs have been found to have antagonistic activity $[19,23,57]$, which our study corroborates. While inhibition of $a g r$ by AIPs is more tolerant of sequence and structural diversity than is activation [23], Mayville et al. [14] found that the presence of the hydrophobic leucine and phenylalanine residues is important for the inhibition of the agr response. Both solonamides contain a leucine and phenylalanine; however, the reduced activity of solonamide A indicates that the overall hydrophobicity of the depsipeptides affected by the varying length of the fatty acid moiety might be an important factor influencing activity.

The solonamides are the first reported antagonists produced by a natural source with a structure resembling that of native $S$. aureus AIPs. Kiran et al. (2008) [25] identified hamamelitannin from Hamamelis virginiana (witch hazel) as an inhibitor of RNAIII and $\delta$-hemolysin production in $S$. aureus 8325-4, USA300, and clinical S. epidermidis isolate MH. Also, ambuic acid from an unidentified fungal 
strain was found to attenuate agr [26].Given the relatively low abundance of staphylococci in the marine environment, it seems unlikely that the Photobacterium sp. S2753 produces solonamides as part of a deliberate strategy to interfere with this specific type of bacteria. However, the solonamides might be targeted at other Gram-positive bacteria in the marine environment, such as bacilli and actinobacteria, though little is known about quorum sensing pathways in marine Gram-positive bacteria. A large number of different QS systems have been characterized from Gram-negative bacteria in the marine environment [57-62]. We speculate that the solonamides could also affect such systems despite sharing little structural similarity to agonists and antagonists of the systems identified to date [63]. Acylated homoserine lactones, the most widely researched type of QS molecules in Gram-negatives, can serve as both agonists and antagonists in different systems [27], and thus the solonamides may also serve as quorum sensing signals for the Photobacterium itself. However, we did not detect solonamides or compounds with similar QSI activity in any of the related strains.

Figure 4. Effect of solonamide $\mathrm{A}$ and $\mathrm{B}$ on virulence gene expression in $S$. aureus strain 8325-4 [18] and USA300 [55] examined by Northern blot analysis. Solonamides were added to exponentially growing cultures at $\mathrm{OD}_{600}=0.4$, and RNA was purified at $\mathrm{OD}_{600}=0.7$ and 1.7. The RNA was reacted with probes recognizing hla, rnaIII, and spa, respectively. Solonamide B tested in duplicates. DMSO was used as negative control.

8325-4

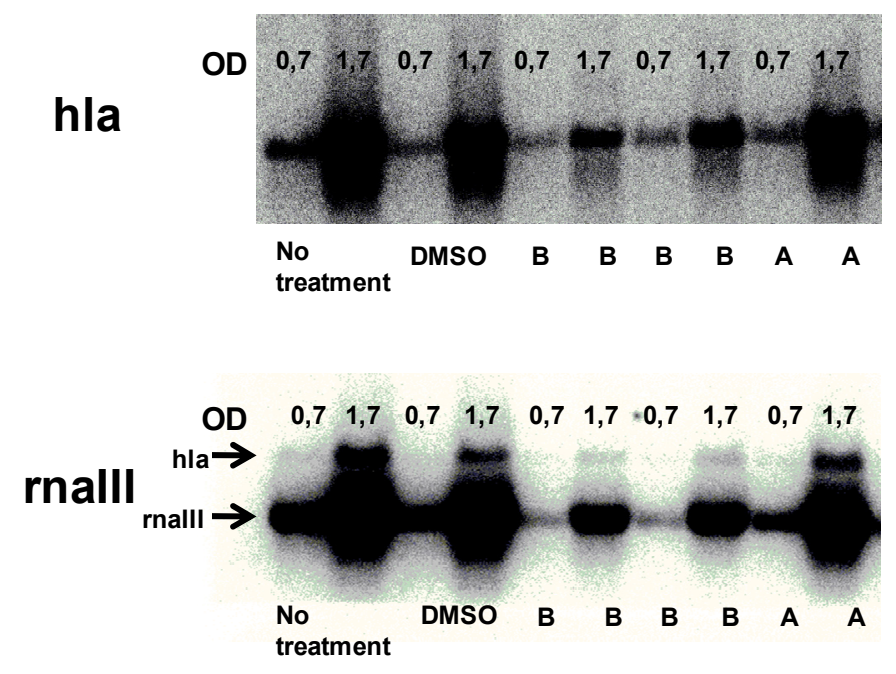

OD

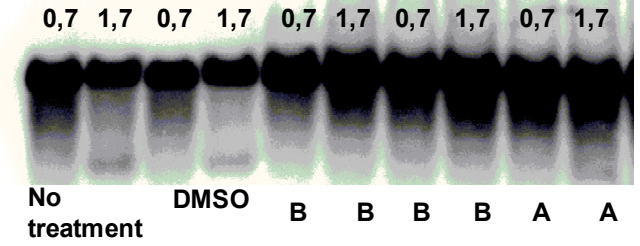

USA300
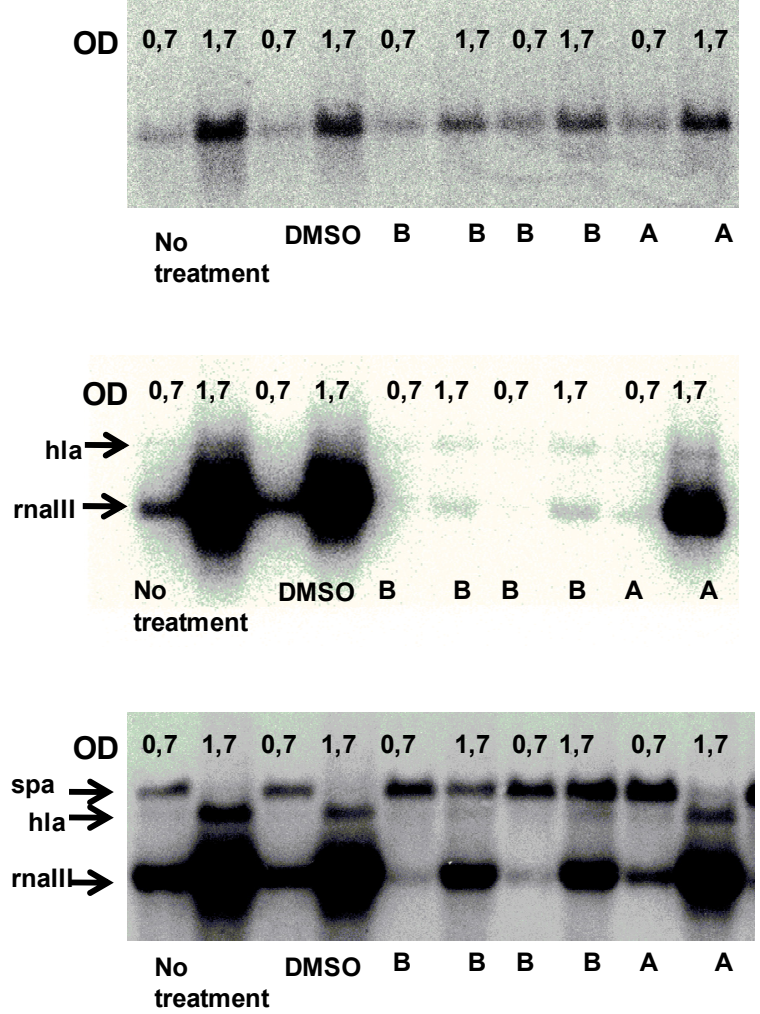

Our findings suggest that quorum sensing inhibition could be an alternative therapeutic strategy for treatment of MRSA $S$. aureus infections; however, the effect in an in vivo infection model needs to be tested. Many genes are under QS control both in Gram-positive and Gram-negative bacteria, and thus it is not a simple drug target $[64,65]$. For example, biofilm formation in $S$. aureus has been linked to 
low QS activity [66], and so there is a risk that the use of QS inhibitors could lead to decreased susceptibility of traditional antibiotics. Also, it is still unknown how QS inhibition will affect the overall fitness of a pathogen under in vivo conditions and thus pose a selective pressure for development of resistance [67] or enhanced virulence [68,69].

\section{Experimental Section}

\subsection{Isolation and Identification of Strain S2753}

Bacterial strain S2753 was isolated from a mussel surface collected in the tropical Pacific $\left(9.1^{\circ} \mathrm{S}\right.$ $156.8^{\circ} \mathrm{E}$ ) during the Danish Galathea 3 expedition [29]. S2753 was assigned to the Vibrionaceae by 16S rRNA gene sequence similarity [29] and identified as being closely related to Photobacterium halotolerans based on recA and rpoA gene sequences, with homologies of $87 \%$ (rec $A$ ) and $94 \%$ $(r p o A)$ [45]. BLAST analyses showed that other closely related species were Photobacterium rosenbergii and Photobacterium angustum S14 [52].

\subsection{Initial Screening for Anti-Virulence Compounds}

S2753 was cultured in each $30 \mathrm{~mL}$ of (i) marine minimal medium (MMM) [70] containing 0.4\% glucose and 0.3\% casamino acids; (ii) Marine Broth 2216 (MB; Difco 2216); (iii) Sigma Sea Salts (SSS; Sigma S9883; $40 \mathrm{~g} \mathrm{~L}^{-1}$ ) containing $0.4 \%$ glucose and $0.3 \%$ casamino acids, and (iv) MMM containing $0.2 \%$ colloidal chitin $[71,72]$ to investigate the best conditions for production of antibacterial compounds. All cultures were incubated aerated $(200 \mathrm{rpm})$ for $72 \mathrm{~h}$ at $25{ }^{\circ} \mathrm{C}$. All cultures were extracted with an equal volume of ethyl acetate (EtOAc). The extract was evaporated under nitrogen until dryness and redissolved in $300 \mu \mathrm{L} 80 \% \mathrm{v} / \mathrm{v}$ ethanol (EtOH) in water. $20 \mu \mathrm{L}$ of the extract was tested in an agar diffusion assay where expression from promoters of hla, rnaIII, and spa is monitored [28].

For further screening, the culture broth of S2753 grown in MMM (1 L, $\left.72 \mathrm{~h}, 25^{\circ} \mathrm{C}, 100 \mathrm{rpm}\right)$ was extracted directly with sterile Diaion HP20SS (12 $\left.\mathrm{g} \mathrm{L}^{-1}, 24 \mathrm{~h}\right)$ (Sigma-Aldrich, St. Louis, MO). The resin was filtered off and washed with $80 \%(\mathrm{v} / \mathrm{v})$ acetonitrile $(\mathrm{MeCN}) /$ water $(300 \mathrm{~mL})$ and the extract evaporated until dryness on a rotary evaporator. From this extract, $10 \mathrm{mg}$ dry material was subjected to an explorative solid-phase extraction (E-SPE) protocol [48]. This yielded 15 fractions for re-testing in the agar diffusion assay as described above. The E-SPE fractions were also tested for antibacterial activity against Vibrio anguillarum strain 90-11-287 and S. aureus 8325 in a well diffusion agar assay [73].

\subsection{Isolation and Structural Elucidation of Solonamide A and B}

Using 10 L glass fermentors, S2753 was cultured in $5 \times 4$ L SSS (iii, above) containing $0.4 \%$ glucose and $0.3 \%$ casamino acids $\left(25^{\circ} \mathrm{C}, 72 \mathrm{~h}, 100 \mathrm{rpm}\right)$ as this medium gave comparable yields to that of MMM (i) but at a lower cost. The broth was extracted directly with Diaion HP20SS (12 $\left.\mathrm{g} \mathrm{L}^{-1}\right)$ as described above. The extract $(3.4 \mathrm{~g})$ was redissolved in EtOAc, absorbed onto $5 \mathrm{~g}$ Isolute diol (Biotage, Uppsala, Sweden), and added to a glass column with pure diol (95 g). A total of 12 fractions were collected from the diol column $(100 \mathrm{~g}, 20 \times 350 \mathrm{~mm})$ ranging from heptane, dichlormethane (DCM), EtOAc, to pure methanol $(\mathrm{MeOH})$, running under gravity. The fractions containing the QSI compounds (fraction 5, 20:80 (v/v) EtOAc/DCM and fraction 6, 40:60 (v/v) EtOAc/DCM) were 
separated on Sepra ZT C 18 (Phenomenex, Torrance, CA)(10 g SNAP) on an Isolera automated flash system (Biotage) using a MeCN/water gradient 25-75\% over $20 \mathrm{~min}\left(12 \mathrm{~mL} \mathrm{~min}{ }^{-1}\right)$. Pure compounds were obtained directly: Solonamide A $(17 \mathrm{mg})$ and B $(201 \mathrm{mg})$. Activity of pure compounds was tested in the agar diffusion assay as described above ( $20 \mu \mathrm{L}$ per well), with a final concentration of compounds of $5 \mathrm{mg} \mathrm{mL}^{-1}$ in dimethyl sulfoxide (DMSO).

NMR spectra were recorded on a Varian Unity Inova $500 \mathrm{MHz}$ spectrometer equipped with a $5 \mathrm{~mm}$ probe using standard pulse sequences. The signals of the solvent were used as internal references $\left(\delta_{\mathrm{H}} 2.49\right.$ and $\delta_{\mathrm{C}} 39.5 \mathrm{ppm}$ for DMSO). Carbonyl shifts were confirmed with ${ }^{13} \mathrm{C} 1 \mathrm{D}$ on a Bruker Avance $800 \mathrm{MHz}$ spectrometer with a $5 \mathrm{~mm}$ TCI cryoprobe at the Danish Instrument Center for NMR Spectroscopy of Biological Macromolecules.

LC-MS and LC-MS/MS analyses were performed on a maXis quadrupole time of flight mass spectrometer (Bruker Daltonics, Bremen, Germany) equipped with an electrospray (ESI) ion source. The MS was connected to an Ultimate 3000 UHPLC system (Dionex, Sunnyvale, CA) equipped with a diode-array detector. Separation was performed at $40{ }^{\circ} \mathrm{C}$ on a $150 \mathrm{~mm} \times 2.1 \mathrm{~mm}$ ID, $2.6 \mu \mathrm{m}$ Kinetex $\mathrm{C}_{18}$ column (Phenomenex) using a linear water/MeCN (both buffered with $20 \mathrm{mM}$ formic acid) gradient starting from $15 \% \mathrm{MeCN}$ and increased to $100 \%$ in $13 \mathrm{~min}$ at a flow of $0.4 \mathrm{~mL} \mathrm{~min}{ }^{-1}$. The MS and MS/MS experiments were performed in $\mathrm{ESI}^{+}$with a data acquisition range of $\mathrm{m} / z$ 100-1200 with collision energy of $27 \mathrm{~V}$. The MS was calibrated using sodium formate automatically infused prior to each analytical run, providing a mass accuracy of below $1 \mathrm{ppm}$ in MS mode and $2 \mathrm{ppm}$ in MS/MS mode.

The absolute configuration of the amino acids were found using acid hydrolysis $(6 \mathrm{M} \mathrm{HCl}$, $110{ }^{\circ} \mathrm{C}, 20 \mathrm{~h}$ ) [74] and derivatisation with Marfey's reagent (1-fluoro-2,4-dinitrophenyl-5-L-alanine amide, FDAA, Sigma-Aldrich) following the protocol by Bonnard et al. [75]. Ultra-high liquid chromatography-diode array (UHPLC-UV) analyses of the amino acids were done on a Dionex RSLC Ultimate 3000 (Dionex) equipped with a diode-array detector. Separation was obtained on a Kinetex $\mathrm{C}_{18}$ column $(150 \times 2.10 \mathrm{~mm}, 2.6 \mu \mathrm{m}$, Phenomenex $)$ maintained at $60{ }^{\circ} \mathrm{C}$ using a linear gradient starting from $25 \% \mathrm{MeCN}$ in water (both buffered with 50 ppm TFA) increasing to $27 \% \mathrm{MeCN}$ over 6 min at a flow rate of $0.8 \mathrm{~mL} \mathrm{~min}{ }^{-1}$. Retention times of the FDAA amino acid derivatives used as standards were as follows (maximum standard deviation $\pm 0.002 \mathrm{~min})$ : FDAA (1.50 min), L-Ala (1.14 min), D-Ala (1.61 $\mathrm{min})$, L-Phe (3.58 $\mathrm{min})$, D-Phe (5.04 $\mathrm{min})$, L-Leu (3.77 $\mathrm{min})$, D-Leu (5.49 $\mathrm{min})$, comparable to the observed retention times from the solonamide-derived amino acids.

To specify the stereochemistry of enantiomeric amino acids, the depsipeptides were reduced by $\mathrm{LiBH}_{4}$. The resulting linear peptides were subjected to the above mentioned acid hydrolysis and Marfey's derivatisation. Details are given in the Supplementary Information.

For the absolute configuration of the fatty acid residues, the $(R)$ - and $(S)$-Mosher's esters were prepared for both depsipeptides, and the stereocenters were assigned based on their ${ }^{1} \mathrm{H}$ and ${ }^{19} \mathrm{~F}$ chemical shift differences $\left(\Delta \delta^{S R}\right)$ [76,77]. Details are given in the Supplementary Information.

Solonamide A: white amorphous solids; UV ( $\left.\mathrm{MeCN} / \mathrm{H}_{2} \mathrm{O}\right) \lambda_{\max } 200 \mathrm{~nm}(100 \%)$; for NMR data refer to Table 1; HRESIMS $m / z 558.3486$ (calcd for $\mathrm{C}_{30} \mathrm{H}_{46} \mathrm{~N}_{4} \mathrm{O}_{6}, 558.3496$ ).

Solonamide B: white amorphous solids; UV (MeCN/H $\left.\mathrm{H}_{2} \mathrm{O}\right) \lambda_{\max } 200 \mathrm{~nm}(100 \%)$; for NMR data refer to Table 1; HRESIMS $m / z 586.3725$ (calcd for $\mathrm{C}_{32} \mathrm{H}_{50} \mathrm{~N}_{4} \mathrm{O}_{6}, 586.3730$ ). 
Table 1. NMR spectroscopic data (DMSO- $d_{6}$ ) of solonamide A and B.

\begin{tabular}{|c|c|c|c|c|c|c|c|c|}
\hline & Atom & $\delta_{\mathrm{C}}(\mathrm{ppm})$ & $\underset{\delta_{\mathrm{H}}(\mathrm{ppm})(\text { multiplicity, } J(\mathrm{~Hz}))}{\mathrm{A}}$ & HMBC & Atom & $\delta_{\mathrm{C}}(\mathrm{ppm})$ & $\begin{array}{c}\text { B } \\
\delta_{\mathrm{H}}(\mathrm{ppm})(\text { multiplicity, } J(\mathrm{~Hz}))\end{array}$ & HMBC \\
\hline \multirow{10}{*}{ Hha/Hoa } & 1 & 170.6 & - & & 1 & 170.4 & - & - \\
\hline & 2 & 40.7 & $2.67(1 \mathrm{H}, \mathrm{dd}, 13.5,3.8)$ & $1,3,4$ & 2 & 40.5 & $2.69(1 \mathrm{H}, \mathrm{dd}, 13.5,3.7)$ & $1,3,4$ \\
\hline & & & $2.11(1 \mathrm{H}, \mathrm{dd}, 13.5,10.1)$ & & & & $2.11(1 \mathrm{H}, \mathrm{dd}, 13.5,10.3)$ & \\
\hline & 3 & 72.1 & $5.14(1 \mathrm{H}, \mathrm{m})$ & 1,5 & 3 & 72.0 & $5.13(1 \mathrm{H}, \mathrm{m})$ & $1,4,5,36$ \\
\hline & 4 & 36.2 & $1.62(1 \mathrm{H}, \mathrm{m})$ & $2,3,6$ & 4 & 33.8 & $1.65(1 \mathrm{H}, \mathrm{m})$ & 5,6 \\
\hline & & & $1.45(1 \mathrm{H}, \mathrm{m})$ & & & & $1.45(1 \mathrm{H}, \mathrm{m})$ & \\
\hline & 5 & 17.7 & $\sim 1.22(1 \mathrm{H}, \mathrm{m})$ & 3,4 & 5 & 23.8 & $\sim 1.20(2 \mathrm{H}, \mathrm{m})$ & 6,7 \\
\hline & 6 & 13.8 & $0.85(3 \mathrm{H}, \mathrm{t}, 7)$ & 4,5 & 6 & 30.8 & $\sim 1.22(2 \mathrm{H}, \mathrm{m})$ & ND \\
\hline & & & & & 7 & 21.8 & $1.25(2 \mathrm{H}, \mathrm{m})$ & ND \\
\hline & & & & & 8 & 13.6 & $0.84(3 \mathrm{H}, \mathrm{m})$ & 6 \\
\hline \multirow{9}{*}{ L-Phe } & $7-\mathrm{NH}$ & - & $8.61(1 \mathrm{H}, \mathrm{d}, 3.2)$ & 1 & 9-NH & - & $8.59(1 \mathrm{H}, \mathrm{d}, 3.0)$ & $1,10,11,8$ \\
\hline & $8-\mathrm{CH}_{\alpha}$ & 55.9 & $4.26(1 \mathrm{H}, \mathrm{ddd}, 10,6.1,3.2)$ & $9,10,14$ & $10-\mathrm{CH}_{\alpha}$ & 55.6 & $4.26(1 \mathrm{H}, \mathrm{ddd}, 10,6.1,3.3)$ & 11,18 \\
\hline & 9- $\mathrm{CH}_{\beta, 1}$ & 36.4 & $2.94(1 \mathrm{H}, \mathrm{dd}, 13.3,6.1)$ & $8,10,11 / 15,14$ & $11-\mathrm{CH}_{\beta, 1}$ & 36.1 & $2.95(1 \mathrm{H}, \mathrm{dd}, 13.3,6.1)$ & $10,12,13 / 17,18$ \\
\hline & & & $2.72(1 \mathrm{H}, \mathrm{dd}, 13.3,10)$ & & & & $2.73(1 \mathrm{H}, \mathrm{dd}, 13.3,10)$ & \\
\hline & 10 & 135.8 & - & - & 12 & 136.0 & - & - \\
\hline & 11,15 & 129.1 & $7.18(2 \mathrm{H}, \mathrm{m})$ & 9,13 & 13,17 & 128.7 & $7.20(2 \mathrm{H}, \mathrm{m})$ & 11,15 \\
\hline & 12,14 & 128.4 & $7.25(2 \mathrm{H}, \mathrm{m})$ & 10 & 14,16 & 128.0 & $7.26(2 \mathrm{H}, \mathrm{m})$ & $12,14 / 16$ \\
\hline & 13 & 126.5 & $7.18(1 \mathrm{H}, \mathrm{m})$ & 11 & 15 & 126.2 & $7.20(1 \mathrm{H}, \mathrm{m})$ & $13 / 17$ \\
\hline & $16-\mathrm{CO}$ & 174.4 & - & - & $18-\mathrm{CO}$ & 174.2 & - & - \\
\hline \multirow{8}{*}{ D-Leu } & $17-\mathrm{NH}$ & - & $8.63(1 \mathrm{H}, \mathrm{d}, 5.6)$ & $16,18,19$ & 19-NH & - & $8.64(1 \mathrm{H}, \mathrm{d}, 5.6)$ & $18,20,21$ \\
\hline & $18-\mathrm{CH}_{\alpha}$ & 53.1 & $3.56(1 \mathrm{H}, \mathrm{m})$ & ND & $20-\mathrm{CH}_{\alpha}$ & 52.7 & $3.57(1 \mathrm{H}, \mathrm{m})$ & $21,22,25$ \\
\hline & $19-\mathrm{CH}_{\beta, 1}$ & 38.9 & $1.36(1 \mathrm{H}, \mathrm{m})$ & $18,21,22$ & $21-\mathrm{CH}_{\beta, 1}$ & 38.6 & $1.31-1.37(2 \mathrm{H}, \mathrm{m})$ & $20,22,24$ \\
\hline & & & $1.29(1 \mathrm{H}, \mathrm{m})$ & & & & & \\
\hline & $20-\mathrm{CH}_{\gamma}$ & 23.5 & $0.97(1 \mathrm{H}, \mathrm{m})$ & 21 & $22-\mathrm{CH}_{\gamma}$ & 23.3 & $0.99(1 \mathrm{H}, \mathrm{m})$ & ND \\
\hline & $21-\mathrm{CH}_{\delta, 1}$ & 23.2 & $0.69(3 \mathrm{H}, \mathrm{d}, 6.6)$ & 19,20 & $23-\mathrm{CH}_{\delta, 1}$ & 22.9 & $0.70(3 \mathrm{H}, \mathrm{d}, 6.6)$ & $21,22,24$ \\
\hline & $22-\mathrm{CH}_{\delta, 1}$ & 20.7 & $0.52(3 \mathrm{H}, \mathrm{d}, 6.5)$ & 19,20 & $24-\mathrm{CH}_{\delta, 1}$ & 20.4 & $0.53(3 \mathrm{H}, \mathrm{d}, 6.4)$ & 21,23 \\
\hline & $23-\mathrm{CO}$ & 171.8 & - & - & $25-\mathrm{CO}$ & 171.6 & - & - \\
\hline \multirow{4}{*}{ D-Ala } & 24-NH & - & $7.53(1 \mathrm{H}, \mathrm{d}, 8.9)$ & 27,29 & $26-\mathrm{NH}$ & - & $7.48(1 \mathrm{H}, \mathrm{d}, 8.9)$ & $25,27,28$ \\
\hline & $25-\mathrm{CH}_{\alpha}$ & 48.2 & $4.18(1 \mathrm{H}, \mathrm{m})$ & 26,27 & $27-\mathrm{CH}_{\alpha}$ & 47.8 & $4.18(1 \mathrm{H}, \mathrm{m})$ & 28,29 \\
\hline & $26-\mathrm{CH}_{\beta, 1}$ & 16.6 & $1.32(3 \mathrm{H}, \mathrm{d}, 7.4)$ & 27 & $28-\mathrm{CH}_{\beta, 1}$ & 16.4 & $1.33(3 \mathrm{H}, \mathrm{d}, 7.3)$ & 27,29 \\
\hline & $27-\mathrm{CO}$ & 171.3 & - & - & $29-\mathrm{CO}$ & 170.9 & - & - \\
\hline \multirow{8}{*}{ L-Leu } & $28-\mathrm{NH}$ & - & $7.08(1 \mathrm{H}, \mathrm{d}, 10)$ & 27,29 & $30-\mathrm{NH}$ & - & $7.05(1 \mathrm{H}, \mathrm{d}, 10)$ & 29,31 \\
\hline & $29-\mathrm{CH}_{\alpha}$ & 49.0 & $4.46(1 \mathrm{H}, \mathrm{dt}, 10,4.4)$ & $30,31,34$ & $31-\mathrm{CH}_{\alpha}$ & 48.6 & $4.47(1 \mathrm{H}, \mathrm{dt}, 10,4.3)$ & $32,33,29 / 36$ \\
\hline & $30-\mathrm{CH}_{\beta, 1}$ & 39.3 & $1.63(1 \mathrm{H}, \mathrm{m})$ & $29,31,33,27 / 34$ & $32-\mathrm{CH}_{\beta, 1}$ & 39.0 & $1.64(1 \mathrm{H}, \mathrm{m})$ & $31,33,35,29 / 36$ \\
\hline & & & $1.53(1 \mathrm{H}, \mathrm{m})$ & & & & $1.52(1 \mathrm{H}, \mathrm{m})$ & \\
\hline & $31-\mathrm{CH}_{\gamma}$ & 23.9 & $1.50(1 \mathrm{H}, \mathrm{m})$ & $29,30,33$ & $33-\mathrm{CH}_{\gamma}$ & 23.8 & $1.50(1 \mathrm{H}, \mathrm{m})$ & $32,34,35$ \\
\hline & $32-\mathrm{CH}_{\delta, 1}$ & 23.2 & $0.86(3 \mathrm{H}, \mathrm{d}, 6.5)$ & $30,31,33$ & $34-\mathrm{CH}_{\delta, 1}$ & 23.0 & $0.86(3 \mathrm{H}, \mathrm{d}, 6.6)$ & $32,33,35$ \\
\hline & $33-\mathrm{CH}_{\delta, 1}$ & 21.3 & $0.81(3 \mathrm{H}, \mathrm{d}, 6.5)$ & 30 & $35-\mathrm{CH}_{\delta, 1}$ & 21.1 & $0.82(3 \mathrm{H}, \mathrm{d}, 6.4)$ & 32,33 \\
\hline & $34-\mathrm{CO}$ & 171.2 & - & - & $36-\mathrm{CO}$ & 170.8 & - & - \\
\hline
\end{tabular}




\subsection{LC-UV/MS Analyses of Related Photobacterium Strains}

To investigate the potential production of agr inhibitors in related Photobacterium strains, the metabolite profile of S2753 was compared by liquid chromatography-diode array/mass spectrometry (LC-UV/MS) to P. halotolerans (LMG $22194^{\mathrm{T}}$ ), P. rosenbergii (LMG $22223^{\mathrm{T}}$ ), and P. angustum $(\mathrm{S} 14)$ described by de Nys et al. [52]. All strains were grown in $30 \mathrm{~mL}$ MMM containing $0.4 \%$ glucose and $0.3 \%$ casamino acids $\left(25^{\circ} \mathrm{C}, 72 \mathrm{~h}, 200 \mathrm{rpm}\right)$. Cultures were extracted with an equal volume of EtOAc and evaporated under nitrogen. Residues were redissolved in $\mathrm{MeOH}$ for LC-UV/MS analyses and in $80 \% \mathrm{EtOH}$ for bioassay testing. Inhibition of agr was tested as described above. Extracts were also tested against $V$. anguillarum strain 90-11-287 for growth inhibition. LC-UV/MS analyses were performed on an Agilent 1100 liquid chromatograph with a diode array detector (Agilent, Waldbronn, Germany) coupled to an LCT TOF mass spectrometer (Micromass, Manchester, UK) using a Z-spray ESI source. Separation was obtained on a Luna II $\mathrm{C}_{18}$ column $(50 \times 2 \mathrm{~mm}, 3 \mu \mathrm{m}$, Phenomenex $)$ fitted with a security guard system using a linear gradient starting from $15 \% \mathrm{MeCN}$ in water (both buffered with $20 \mathrm{mM}$ formic acid) increasing to $100 \% \mathrm{MeCN}$ over $20 \mathrm{~min}$ at a flow rate of $0.3 \mathrm{~mL} \mathrm{~min}{ }^{-1}$.

\subsection{Northern Blot Analysis}

Northern blot analysis was performed as described previously [78]. The strains used were $S$. aureus FPR 3757 [55], a CA-MRSA USA300 obtained from ATCC (Boras, Sweden), and 8325-4 [17]. Samples for RNA purification were taken from cultures in Tryptone Soya Broth (TSB, Oxoid, Greve, Denmark) shaking at $185 \mathrm{rpm}$ at $37^{\circ} \mathrm{C}$ in a water bath $(10 \mathrm{~mL}$ culture in $100 \mathrm{~mL}$ Erlenmeyer flask). Growth was monitored by measuring optical density at $\mathrm{OD}_{600}$. Start inoculum was $\mathrm{OD}_{600}=0.03$. Solonamides were added at $\mathrm{OD}_{600}=0.4$. Samples for RNA purification were taken at $\mathrm{OD}_{600}=0.7$ and 1.7. Probes targeting rnaIII, spa, and hla transcripts were amplified by PCR using primers hla forward (5'-GGG TTA GCC TGG CCT TCA GCC-3'), hla reverse (5'-GGG TGC CAT ATA CCG GGT TC-3'), spa forward (5'-GGG GGT GTA GGT ATT GCA TCT G-3'), spa reverse (5'-GGG GCT CCT GAA GGA TCG TC-3'), rnaIII forward (5'-GGG GAT CAC AGA GAT GTG ATG-3'), and rnaIII reverse (5'-GGG CAT AGC ACT GAG TCC AAG G-3')(TAG Copenhagen A/S, Denmark). The resulting PCR fragments were 311 bp (hla), 719 bp (spa), and 316 bp (rnaIII), respectively.

\section{Conclusions}

The rapid, worldwide increase in antibiotic-resistant $S$. aureus [15] has led to an intense search for compounds with potential use in alternative therapeutic strategies [9]. Virulence of $S$. aureus involves a complex set of proteins, with the agr QS system controlling expression of several of the virulence genes. The investigation of crude extracts and fractions from a marine Photobacterium led to the identification of two novel depsipeptides, solonamides A and B, as potent inhibitors of this system. Interestingly, we found that solonamide B interfered with agr not only in S. aureus 8325-4 but also in strain USA300, which is a predominant community-acquired MRSA (CA-MRSA) strain in the US [79]. This finding suggests that quorum sensing inhibition could be an option for treatment of $S$. aureus USA300 infections. Future experiments will reveal the extent to which the solonamides are effective in treating S. aureus infections. In combination with other recent work from our laboratory $[42,45,71]$ 
the present study underlines that vibrios are a promising potential source of novel bioactive secondary metabolites.

\section{Acknowledgments}

We thank Anita Iversen for ultra high-resolution MS data and the Danish Center for NMR Spectroscopy of Biological Macromolecules for NMR time. Funding from the Programme Committee for Food, Health and Welfare under the Danish Strategic Research Council is acknowledged. The present work was carried out as part of the Galathea 3 expedition under the auspices of the Danish Expedition foundation. This is Galathea 3 contribution $\mathrm{p} 85$.

\section{References}

1. Berdy, J. Bioactive microbial metabolites-A personal view. J. Antibiot. 2005, 58, 1-26.

2. Clardy, J.; Fischbach, M.A.; Walsh, C.T. New antibiotics from bacterial natural products. Nat. Biotechnol. 2006, 24, 1541-1550.

3. Das, S.; Lyla, P.S.; Khan, S.A. Marine microbial diversity and ecology: Importance and future perspectives. Curr. Sci. 2006, 90, 1325-1335.

4. Gulder, T.A.M.; Moore, B.S. Chasing the treasures of the sea-Bacterial marine natural products. Curr. Opin. Microbiol. 2009, 12, 252-260.

5. Rahman, H.; Austin, B.; Mitchell, W.J.; Morris, P.C.; Jamieson, D.J.; Adams, D.R.; Spragg, A.M.; Schweizer, M. Novel anti-infective compounds from marine bacteria. Mar. Drugs 2010, 8, 498-518.

6. de Carvalho, C.C.C.R.; Fernandes, P. Production of metabolites as bacterial responses to the marine environment. Mar. Drugs 2010, 8, 705-727.

7. Long, R.A.; Azam, F. Antagonistic interactions among marine pelagic bacteria. Appl. Environ. Microbiol. 2001, 67, 4975-4983.

8. Wright, G.D.; Sutherland, A.D. New strategies for combating multidrug-resistant bacteria. Trends Mol. Med. 2007, 13, 260-267.

9. Clatworthy, A.E.; Pierson, E.; Hung, D.T. Targeting virulence: A new paradigm for antimicrobial therapy. Nat. Chem. Biol. 2007, 3, 541-548.

10. Rasmussen, T.B.; Givskov, M. Quorum-sensing inhibitors as anti-pathogenic drugs. Int. J. Med. Microbiol. 2006, 296, 149-161.

11. Sintim, H.O.; Al Smith, J.; Wang, J.X.; Nakayama, S.; Yan, L. Paradigm shift in discovering next-generation anti-infective agents: Targeting quorum sensing, c-di-gmp signaling and biofilm formation in bacteria with small molecules. Future Med. Chem. 2010, 2, 1005-1035.

12. Bjarnsholt, T.; Givskov, M. Quorum-sensing blockade as a strategy for enhancing host defences against bacterial pathogens. Philos. Trans. R. Soc. Lond. B Biol. Sci. 2007, 362, 1213-1222.

13. Camara, M.; Williams, P.; Hardman, A. Controlling infection by tuning in and turning down the volume of bacterial small-talk. Lancet Infect. Dis. 2002, 2, 667-676.

14. Mayville, P.; Ji, G.Y.; Beavis, R.; Yang, H.M.; Goger, M.; Novick, R.P.; Muir, T.W. Structure-activity analysis of synthetic autoinducing thiolactone peptides from Staphylococcus aureus responsible for virulence. Proc. Natl. Acad. Sci. USA 1999, 96, 1218-1223. 
15. Grundmann, H.; Aires-De-Sousa, M.; Boyce, J.; Tiemersma, E. Emergence and resurgence of meticillin-resistant Staphylococcus aureus as a public-health threat. Lancet 2006, 368, 874-885.

16. Hiramatsu, K.; Cui, L.; Kuroda, M.; Ito, T. The emergence and evolution of methicillin-resistant Staphylococcus aureus. Trends Microbiol. 2001, 9, 486-493.

17. Chan, W.C.; Coyle, B.J.; Williams, P. Virulence regulation and quorum sensing in staphylococcal infections: Competitive agrc antagonists as quorum sensing inhibitors. J. Med. Chem. 2004, 47, 4633-4641.

18. Novick, R.P.; Morse, S.I. In vivo transmission of drug resistance factors between strains of Staphylococcus aureus. J. Exp. Med. 1967, 125, 45-59.

19. McDowell, P.; Affas, Z.; Reynolds, C.; Holden, M.T.G.; Wood, S.J.; Saint, S.; Cockayne, A.; Hill, P.J.; Dodd, C.E.R.; Bycroft, B.W.; Chan, W.C.; Williams, P. Structure, activity and evolution of the group i thiolactone peptide quorum-sensing system of Staphylococcus aureus. Mol. Microbiol. 2001, 41, 503-512.

20. Novick, R.P. Autoinduction and signal transduction in the regulation of staphylococcal virulence. Mol. Microbiol. 2003, 48, 1429-1449.

21. Ji, G.Y.; Beavis, R.C.; Novick, R.P. Cell density control of staphylococcal virulence mediated by an octapeptide pheromone. Proc. Natl. Acad. Sci. USA 1995, 92, 12055-12059.

22. Ji, G.Y.; Beavis, R.; Novick, R.P. Bacterial interference caused by autoinducing peptide variants. Science 1997, 276, 2027-2030.

23. Lyon, G.J.; Wright, J.S.; Muir, T.W.; Novick, R.P. Key Determinants of Receptor Activation in the Agr Autoinducing Peptides of Staphylococcus aureus. Biochemistry 2002, 41, 10095-10104.

24. Muir, T.W. Turning virulence on and off in staphylococci. J. Pept. Sci. 2003, 9, 612-619.

25. Kiran, M.D.; Adikesavan, N.V.; Cirioni, O.; Giacometti, A.; Silvestri, C.; Scalise, G.; Ghiselli, R.; Saba, V.; Orlando, F.; Shoham, M.; Balaban, N. Discovery of a quorum-sensing inhibitor of drug-resistant staphylococcal infections by structure-based virtual screening. Mol. Pharmacol. 2008, 73, 1578-1586.

26. Nakayama, J.; Uemura, Y.; Nishiguchi, K.; Yoshimura, N.; Igarashi, Y.; Sonomoto, K. Ambuic acid inhibits the biosynthesis of cyclic peptide quormones in gram-positive bacteria. Antimicrob. Agents Chemother. 2009, 53, 580-586.

27. Qazi, S.; Middleton, B.; Muharram, S.H.; Cockayne, A.; Hill, P.; O’Shea, P.; Chhabra, S.R.; Camara, M.; Williams, P. $\mathrm{N}$-acylhomoserine lactones antagonize virulence gene expression and quorum sensing in Staphylococcus aureus. Infect. Immun. 2006, 74, 910-919.

28. Nielsen, A.; Nielsen, K.F.; Frees, D.; Larsen, T.O.; Ingmer, H. Method for screening compounds that influence virulence gene expression in Staphylococcus aureus. Antimicrob. Agents Chemother. 2010, 54, 509-512.

29. Gram, L.; Melchiorsen, J.; Bruhn, J.B. Antibacterial activity of marine culturable bacteria collected from a global sampling of ocean surface waters and surface swabs of marine organisms. Mar. Biotechnol. 2010, 12, 439-451.

30. Thompson, F.L.; Iida, T.; Swings, J. Biodiversity of vibrios. Microbiol. Mol. Biol. Rev. 2004, 68, 403-435.

31. Faruque, S.M.; Albert, M.J.; Mekalanos, J.J. Epidemiology, genetics, and ecology of toxigenic Vibrio cholerae. Microbiol. Mol. Biol. Rev. 1998, 62, 1301-1314. 
32. Linkous, D.A.; Oliver, J.D. Pathogenesis of Vibrio vulnificus. FEMS Microbiol. Lett. 1999, 174, 207-214.

33. Su, Y.C.; Liu, C.C. Vibrio parahaemolyticus: A concern of seafood safety. Food Microbiol. 2007, 24, 549-558.

34. Fidopiastis, P.M.; von Boletzky, S.; Ruby, E.G. A new niche for Vibrio logei, the predominant light organ symbiont of squids in the genus Sepiola. J. Bacteriol. 1998, 180, 59-64.

35. Haygood, M.G.; Distel, D.L. Bioluminescent symbionts of flashlight fishes and deep-sea anglerfishes form unique lineages related to the genus Vibrio. Nature 1993, 363, 154-156.

36. Ruby, E.G. Lessons from a cooperative, bacterial-animal association: The Vibrio fischeri Euprymna scolopes light organ symbiosis. Annu. Rev. Microbiol. 1996, 50, 591-624.

37. Ast, J.C.; Dunlap, P.V. Phylogenetic resolution and habitat specificity of members of the Photobacterium phosphoreum species group. Environ. Microbiol. 2005, 7, 1641-1654.

38. Boisvert, H.; Chatelai, R.; Bassot, J.M. Studies on a Photobacterium isolated from light organ of fish Leiognathidae. Ann. Inst. Pasteur 1967, 112, 521-525.

39. Magarinos, B.; Romalde, J.L.; Lopez-Romalde, S.; Morinigo, M.A.; Toranzo, A.E. Pathobiological characterisation of Photobacterium damselae subsp piscicida isolated from cultured sole (Solea senegalensis). Bull. Eur. Assoc. Fish Pathol. 2003, 23, 183-190.

40. Thompson, F.L.; Thompson, C.C.; Naser, S.; Hoste, B.; Vandemeulebroecke, K.; Munn, C.; Bourne, D.; Swings, J. Photobacterium rosenbergii sp. nov. and Enterovibrio coralii sp. nov., vibrios associated with coral bleaching. Int. J. Syst. Evol. Microbiol. 2005, 55, 913-917.

41. Richards, G.P.; Watson, M.A.; Crane, E.J., III; Burt, I.G.; Bushek, D. Shewanella and Photobacterium spp. in oysters and seawater from delaware bay. Appl. Environ. Microbiol. 2008, 74, 3323-3327.

42. Mansson, M.; Gram, L.; Larsen, T.O. Production of bioactive secondary metabolites by marine Vibrionaceae. Mar. Drugs 2011, 9, 1440-1468.

43. Long, R.A.; Rowley, D.C.; Zamora, E.; Liu, J.Y.; Bartlett, D.H.; Azam, F. Antagonistic interactions among marine bacteria impede the proliferation of Vibrio cholerae. Appl. Environ. Microbiol. 2005, 71, 8531-8536.

44. Oclarit, J.M.; Okada, H.; Ohta, S.; Kaminura, K.; Yamaoka, Y.; Iizuka, T.; Miyashiro, S.; Ikegami, S. Anti-bacillus substance in the marine sponge, hyatella species, produced by an associated Vibrio species bacterium. Microbios 1994, 78, 7-16.

45. Wietz, M.; Mansson, M.; Gotfredsen, C.H.; Larsen, T.O.; Gram, L. Antibacterial compounds from marine Vibrionaceae isolated on a global expedition. Mar. Drugs 2010, 8, 2946-2960.

46. Needham, J.; Kelly, M.T.; Ishige, M.; Andersen, R.J. Andrimid and moiramides A-C, metabolites produced in culture by a marine isolate of the bacterium Pseudomonas fluorescens-Structure elucidation and biosynthesis. J. Org. Chem. 1994, 59, 2058-2063.

47. Pohlmann, J.; Lampe, T.; Shimada, M.; Nell, P.G.; Pernerstorfer, J.; Svenstrup, N.; Brunner, N.A.; Schiffer, G.; Freiberg, C. Pyrrolidinedione derivatives as antibacterial agents with a novel mode of action. Bioorg. Med. Chem. Lett. 2005, 15, 1189-1192.

48. Mansson, M.; Phipps, R.K.; Gram, L.; Munro, M.H.G.; Larsen, T.O.; Nielsen, K.F. Explorative Solid-Phase Extraction (E-SPE) for accelerated microbial natural product discovery, dereplication, and purification. J. Nat. Prod. 2010, 73, 1126-1132. 
49. Nyberg, N.T.; Duus, J.O.; Sorensen, O.W. Heteronuclear two-bond correlation: Suppressing heteronuclear three-bond or higher nmr correlations while enhancing two-bond correlations even for vanishing (2)J(CH). J. Am. Chem. Soc. 2005, 127, 6154-6155.

50. Fenical, W. Chemical studies of marine-bacteria-Developing a new resource. Chem. Rev. 1993, 93, 1673-1683.

51. Oku, N.; Kawabata, K.; Adachi, K.; Katsuta, A.; Shizuri, Y. Unnarmicins A and C, new antibacterial depsipeptides produced by marine bacterium Photobacterium sp. MBIC06485. J. Antibiot. 2008, 61, 11-17.

52. de Nys, R.; Kumar, N.; Sharara, K.A.; Srinivasan, S.; Ball, G.; Kjelleberg, S. A new metabolite from the marine bacterium Vibrio angustum S14. J. Nat. Prod. 2001, 64, 531-532.

53. Matsuura, S.; Odaka, M.; Sugimoto, T.; Goto, T. Structure of pteridines from Photobacterium phosphorium. Chem. Lett. 1973, 2, 343-346.

54. Suzuki, A.; Goto, M. Photolumazines, new naturally occurring inhibitors of riboflavin synthetase. Biochim. Biophys. Acta 1973, 313, 229-234.

55. Diep, B.A.; Gill, S.R.; Chang, R.F.; Phan, T.H.; Chen, J.H.; Davidson, M.G.; Lin, F.; Lin, J.; Carleton, H.A.; Mongodin, E.F.; Sensabaugh, G.F.; Perdreau-Remington, F. Complete genome sequence of USA300, an epidemic clone of community-acquired meticillin-resistant Staphylococcus aureus. Lancet 2006, 367, 731-739.

56. Li, M.; Diep, B.A.; Villaruz, A.E.; Braughton, K.R.; Jiang, X.F.; Deleo, F.R.; Chambers, H.F.; $\mathrm{Lu}, \mathrm{Y}$;; Otto, M. Evolution of virulence in epidemic community-associated methicillin-resistant Staphylococcus aureus. Proc. Natl. Acad. Sci. USA 2009, 106, 5883-5888.

57. Cao, J.G.; Meighen, E.A. Purification and structural identification of an autoinducer for the luminescence system of Vibrio harveyi. J. Biol. Chem. 1989, 264, 21670-21676.

58. Chen, X.; Schauder, S.; Potier, N.; Van Dorsselaer, A.; Pelczer, I.; Bassler, B.L.; Hughson, F.M. Structural identification of a bacterial quorum-sensing signal containing boron. Nature 2002, 415, 545-549.

59. Higgins, D.A.; Pomianek, M.E.; Kraml, C.M.; Taylor, R.K.; Semmelhack, M.F.; Bassler, B.L. The major vibrio cholerae autoinducer and its role in virulence factor production. Nature 2007, 450, 883-886.

60. Kuo, A.; Blough, N.V.; Dunlap, P.V. Multiple N-Acyl-L-homoserine lactone autoinducers of luminescence in the marine symbiotic bacterium Vibrio fischeri. J. Bacteriol. 1994, 176, 7558-7565.

61. Milton, D.L.; Hardman, A.; Camara, M.; Chhabra, S.R.; Bycroft, B.W.; Stewart, G.S.A.B.; Williams, P. Quorum sensing in Vibrio anguillarum: Characterization of the VanI/VanR locus and identification of the autoinducer $N$-(3-Oxodecanoyl)-L-homoserine lactone. J. Bacteriol. 1997, 179, 3004-3012.

62. Schaefer, A.L.; Greenberg, E.P.; Oliver, C.M.; Oda, Y.; Huang, J.J.; Bittan-Banin, G.; Peres, C.M.; Schmidt, S.; Juhaszova, K.; Sufrin, J.R.; Harwood, C.S. A new class of homoserine lactone quorum-sensing signals. Nature 2008, 454, 595-599.

63. Dobretsov, S.; Teplitski, M.; Paul, V. Mini-review: Quorum sensing in the marine environment and its relationship to biofouling. Biofouling 2009, 25, 413-427.

64. Harraghy, N.; Kerdudou, S.; Herrmann, M. Quorum-sensing systems in staphylococci as therapeutic targets. Anal. Bioanal. Chem. 2007, 387, 437-444. 
65. Otto, M. Quorum-sensing control in staphylococci-A target for antimicrobial drug therapy. FEMS Microbiol. Lett. 2004, 241, 135-141.

66. Boles, B.R.; Horswill, A.R. agr-mediated dispersal of Staphylococcus aureus biofilms. PLoS Pathog. 2008, 4, 1-13.

67. Defoirdt, T.; Boon, N.; Bossier, P. Can bacteria evolve resistance to quorum sensing disruption. PLoS Pathog. 2010, 6, 1-6.

68. Köhler, T.; Perron, G.G.; Buckling, A.; van Delden, C. Quorum sensing inhibition selects for virulence and cooperation in Pseudomonas aeruginosa. PLoS Pathog. 2010, 6, 1-6.

69. Rumbaugh, K.P.; Diggle, S.P.; Watters, C.M.; Ross-Gillespie, A.; Griffin, A.S.; West, S.A. Quorum sensing and social evolution of bacterial virulence. Curr. Biol. 2009, 19, 341-345.

70. Ostling, J.; Goodman, A.; Kjelleberg, S. Behavior of incp-1 plasmids and a minimu transposon in a marine Vibrio sp.--Isolation of starvation inducible lac operon fusions. FEMS Microbiol. Ecol. 1991, 86, 83-94.

71. Wietz, M.; Mansson, M.; Gram, L. Chitin stimulates production of the antibiotic andrimid in a Vibrio coralliilyticus strain. Environ. Microbiol. Rep. 2011, 3, 559-564.

72. Weyland, H.; Ruger, H.-J.; Schwarz, H. Zur Isolierung und identifizierung mariner bakterien. Ein beitrag zur standardisierung und entwicklung adaequater methoden. Veroff. Inst. Meeresforsch. Bremerh. 1970, 12, 269-296.

73. Hjelm, M.; Bergh, O.; Riaza, A.; Nielsen, J.; Melchiorsen, J.; Jensen, S.; Duncan, H.; Ahrens, P.; Birkbeck, H.; Gram, L. Selection and identification of autochthonous potential probiotic bacteria from turbot larvae (Scophthalmus maximus) rearing units. Syst. Appl. Microbiol. 2004, 27, 360-371.

74. Fujii, K.; Ikai, Y.; Oka, H.; Suzuki, M.; Harada, K. A nonempirical method using LC/MS for determination of the absolute configuration of constituent amino acids in a peptide: Combination of marfey's method with mass spectrometry and its practical application. Anal. Chem. 1997, 69, 5146-5151.

75. Bonnard, I.; Manzanares, I.; Rinehart, K.L. Stereochemistry of kahalalide F. J. Nat. Prod. 2003, $66,1466-1470$.

76. Dale, J.A.; Dull, D.L.; Mosher, H.S. Alpha-methoxy-alpha-trifluoromethylphenylacetic acid, a versatile reagent for determination of enantiomeric composition of alcohols and amines. J. Org. Chem. 1969, 34, 2543-2549.

77. Sullivan, G.R.; Dale, J.A.; Mosher, H.S. Correlation of configuration and f-19 chemical-shifts of alpha-methoxy-alpha-trifluoromethylphenylacetate derivatives. J. Org. Chem. 1973, 38, 2143-2147.

78. Jelsbak, L.; Ingmer, H.; Valihrach, L.; Cohn, M.T.; Christiansen, M.H.G.; Kallipolitis, B.H.; Frees, D. The chaperone clpx stimulates expression of Staphylococcus aureus protein a by rot dependent and independent pathways. PLoS One 2010, 5, e12752:1-e12752:11.

79. Tenover, F.C.; Goering, R.V. Methicillin-resistant Staphylococcus aureus strain USA300: Origin and epidemiology. J. Antimicrob. Chemother. 2009, 64, 441-446.

Samples Availability: Available from the authors.

(C) 2011 by the authors; licensee MDPI, Basel, Switzerland. This article is an open access article distributed under the terms and conditions of the Creative Commons Attribution license (http://creativecommons.org/licenses/by/3.0/). 